\title{
Quantifying Bioavailability and Toxicity of Copper to Americamysis bahia - Mysid Shrimp
}

\author{
Andrea M. Dietrich, Niel Postlethwait, and Daniel L. Gallagher
}

\begin{abstract}
Reliable methods are needed to measure and correlate bioavailable metals with aquatic toxicity. This research develops a method to measure bioavailable copper in estuarine waters using the cation exchange resin Chelex $100^{\circledR}$. The Chelex $100^{\circledR}$ method performed consistently at copper concentrations from $195-495 \mu \mathrm{g} / \mathrm{L}$ when organic matter, $\mathrm{pH}$ and salinity were held constant. Varying salinity from $15-30$ ppt did not affect measured bioavailable copper. As expected, an increase in $\mathrm{pH}$ from 4 to 8.5 and increase in NOM from 0 to 12.5 $\mathrm{mg} / \mathrm{L}$ reduced measured bioavailable copper. Acute toxicity bioassays were performed with mysid shrimp (Americamysis bahia) and copper in the presence of NOM. At 20 ppt salinity, 48-hour $\mathrm{LC}_{50}$ dissolved copper concentrations were 200, 340, and $495 \mu \mathrm{g} / \mathrm{L}$ at 0,12 , and $24 \mathrm{mg} / \mathrm{L}$ NOM, respectively. The corresponding 48-hour $\mathrm{LC}_{50}$ values for bioavailable copper were nearly constant: 94,98 , and $105 \mu \mathrm{g} / \mathrm{L} \mathrm{Cu}$ at 0,12 , and 24 $\mathrm{mg} / \mathrm{L}$ NOM respectively. The consistency of the mysid shrimp $\mathbf{L C}_{50}$ values for bioavailable copper measured using the Chelex-100 ${ }^{\circledR}$ method indicates that this method is appropriate for evaluating metal bioavailability in saline waters.
\end{abstract}

Index Terms-Bioavailable, copper, salinity, shrimp, toxicity.

\section{INTRODUCTION}

While copper $(\mathrm{Cu})$ is essential for the normal growth and metabolism of living organisms, it is among the most toxic metals to freshwater and marine biota [1], [2]. Anthropogenic sources of copper to surface waters are numerous and include storm water runoff from roads, lawns, and agricultural fields; discharge of municipal and industrial wastewaters; copper released from brake linings; leaching from copperchromium-arsenic (CCA) treated wood; corrosion; pesticides and algaecides, such as copper sulfate applied for algae control [3] - [5].

Once released to the aquatic environment, low dissolved copper concentrations in the range of $1-10 \mu \mathrm{g} / \mathrm{L}$ tend to affect small aquatic organisms such as diatoms and invertebrates, while higher concentrations in the range of 100-1000 $\mu \mathrm{g} / \mathrm{L}$ typically produce toxic effects in fish [6]. Copper toxicity varies by organism and life stage [2], [7], [8]. The larval stage of Mytilus edulis cannot survive in total copper concentrations greater than $400 \mu \mathrm{g} / \mathrm{L}$, while $6 \mu \mathrm{g} / \mathrm{L}$ total

Manuscript received December 10, 2012; revised January 18, 2013. This work was supported in part by Virginia Department of Agriculture and Consumer Services in cooperation with the Virginia Pesticide Control Board; the Virginia Sea Grant program; and the Edna Bailey Sussman Foundation.

A. M. Dietrich and D. L. Gallagher are with the Department of Civil and Environmental Engineering, Virginia Tech, Blacksburg VA 24060-0246 (e-mail: andread@vt.edu; dang@vt.edu).

N. Postlethwait is an Associate Project Manager at CH2M HILL, Tampa, FL 33607, (e-mail: niel.postlethwait@ch2m.com). The research was conducted when he was a graduate student at the Department of Civil and Environmental Engineering, Virginia Tech, Blacksburg VA 24060-0246. copper is toxic to its embryonic form [9]. Larval crabs (Cancer magister) and sand shrimp (Crangon crangon) are 10-100 times more sensitive to metals than their adult forms [8]. Some organisms, including filter feeders such as larval clams, both uptake soluble metals and also mobilize metals from ingested metal-contaminated particles and food [10].

An issue with copper and other metals in aquatic environments is what portion of the total metal concentration causes toxic effects to biota. In the early 1990's, regulatory standards for monitoring aqueous metals were changed from total to dissolved metal because research showed that metals strongly bound in the particulate phase were not readily toxic [11]. Even within the dissolved phase, metals may complex with dissolved organic matter or form inorganic species to reduce metal toxicity. Conceptually, bioavailable metal is that portion of the total metal that interacts with an organism in its environment [6]. To completely understand copper's toxic biological interactions, the relationship between labile $\mathrm{Cu}^{2+}$ and dissolved and total copper must be evaluated. Major factors that influence the bioavailability of copper in saltwater organisms include: type, size and age of the organism, copper concentration and speciation in water and food, exposure routes, and environmental characteristics such as $\mathrm{pH}$, temperature, alkalinity, hardness, natural organic matter (NOM), and turbidity [12]. Because of these intricacies, the measurement of potentially harmful copper is a difficult task.

Numerous copper species simultaneously coexist under natural aquatic conditions and are controlled by $\mathrm{pH}$, redox, and water chemistry constituents [13] - [15]. In estuarine and seawater, the major soluble species of copper are cupric ion $\left(\mathrm{Cu}^{2+}\right)$ plus inorganic complexes including hydroxo (e.g., $\mathrm{CuOH}^{+}$), carbonato (e.g., $\mathrm{CuCO}_{3}{ }^{\circ}$ ), and chloro (e.g., $\mathrm{CuCl}^{+}$) [16]. Labile copper and hydroxo complexes are considered highly toxic and bioavailable. Copper-carbonate and copper-organic ligand species are considered nontoxic [14].

Organic chelators, such as EDTA and dissolved organic matter, complex cupric ions to generally decrease toxicity [17]- [23], although increased toxicity is sometimes observed [24]. In seawater, organic matter content varies between 0.3 and $5 \mathrm{mg} / \mathrm{L}$ of carbon; about $90 \%$ of the dissolved copper is sorbed to this NOM [25]. Typical concentrations of NOM in freshwater rivers and estuaries range from 2 to $20 \mathrm{mg} / \mathrm{L}$. Humic substances account for approximately $60 \%$ of the total NOM in southeastern US estuaries [26]. Humic and fulvic substances are contributors to both strong and weak ligands in coastal systems [26], [27]. Suwannee River humic and fulvic acids were estimated to bind 8 to $10 \mathrm{nM}$ copper per $\mathrm{mg} / \mathrm{L}$ of humic material [27]. For different dissolved organic matters, the overall binding density is estimated to be 4.55 $\mathrm{mmol} \mathrm{Cu/g} \mathrm{C} \mathrm{[28].} \mathrm{In} \mathrm{estuarine} \mathrm{waters,} \mathrm{copper} \mathrm{sorbs} \mathrm{to} \mathrm{the}$ 
organic suspended material and sediment [29], then can be released when the salinity changes [30].

Copper specific electrodes [28], voltammetry [31] and ion exchange [32] have been used to estimate bioavailable copper in freshwater systems but have limited application in saline waters. Although copper specific electrodes successfully measure labile copper concentrations in freshwater systems, this method is vulnerable to chloride ion interferences in seawater. Ion exchange and voltammetry have not been well developed to measure copper in saline water.

Chelex $100^{\circledR}$ resin, a styrene-divinylbenzene copolymer with imminodiacetate functional groups, sorbs free metals and weak complexes through ion exchange; it has been applied to study copper in fresh and saline waters [32] - [37]. Cupric ions and weak copper complexes bind to the resin and conceptually represent a measure of bioavailable copper. Copper strongly bound to organic or inorganic ligands pass through the Chelex $100^{\circledR}$ resin and are not considered bioavailable. One major advantage of the Chelex $100^{\circledR}$ resin technique is the ability to process samples in the field, and then determine metal concentrations in the laboratory using standard techniques such as atomic absorption.

Bioavailable copper measurements are especially relevant to estuaries, which are a breeding ground for many marine species and therefore home to many embryonic and larval stages. Estuaries also receive many discharges of municipal and industrial wastewater effluents and copper-laden agriculture runoff [2], [5]. Coastal farmers routinely apply copper-based pesticides to crops and in animal feed, and studies have shown that $16-240 \mu \mathrm{g} / \mathrm{L}$ of dissolved copper are present in agricultural runoff with concentrations of dissolved copper in the receiving estuary as high as $120 \mu \mathrm{g} / \mathrm{L}$ [29].

Bioavailability may be better comprehended if a bioassay is utilized simultaneously with a study of the copper chemistry in an ecosystem. This research performed such an investigation. The objectives were to: 1) evaluate the ability of Chelex $100^{\circledR}$ resin to measure bioavailable copper species in saline water under varying $\mathrm{pH}$ and NOM conditions; 2) perform acute copper toxicity tests with mysid shrimp (Americamysis bahia); 3) determine total, dissolved, and resin-bound copper $\mathrm{LC}_{50}$ (lethal concentration at which $50 \%$ of the organisms die) and $\mathrm{EC}_{50}$ (effective concentration at which $50 \%$ of the organisms were immobilized) values for mysid shrimp under conditions of varying NOM.

\section{MethodS}

\section{A. Chelex $100^{\circledR}$ Resin: Preparation and Evaluation}

Fisherbrand ${ }^{\circledR}$ Fisher Scientific (Pittsburgh, Pennsylvania), chemicals, containers, and glassware were used exclusively unless otherwise specified. A Fisherbrand ${ }^{\circledR} 1000 \mathrm{mg} / \mathrm{L}$ copper nitrate certified copper reference solution was used to prepare copper solutions. Sample containers and glassware were soaked in $10 \%$ trace metal grade nitric acid for at least 8 hours, washed three times with distilled water, and then washed three times using Nanopure ${ }^{\mathrm{TM}}$ water.
Chelex $100^{\circledR}$ ion exchange resin, Bio-Rad (Hercules, California) \#142-2842, was prepared as previously described [38]. The resin slurry was packed into small liquid chromatography columns for water sampling. Fig. 1 depicts the column design. Items 1 through 7 in Fig. 1 were soaked in $10 \%$ trace metal grade nitric acid bath for two hours and rinsed with reagent water. The columns were then submerged three times in distilled water, rinsed with $30 \mathrm{~mL}$ Nanopure ${ }^{\text {тм }}$ water, air dried, and then weighed using a Model 100A Denver Instrument Company analytical balance. The resin slurry was drawn into the columns using an acid-washed 60 cc plastic syringe. Excess water was removed and each column was adjusted to $0.085 \mathrm{~g}$ on a dry weight basis. A second $1 / 4$ " $\times 1 / 4$ " polyester frit, $1 / 16$ " id Teflon tubing, and zip tie were added to retain the resin. To precondition the resin, 4 $\mathrm{mL}$ of $2 \mathrm{M}$ calcium chloride was passed through each column, followed by $30 \mathrm{~mL}$ Nanopure ${ }^{\mathrm{TM}}$ water using a KD Scientific (Boston, Massachusetts) 220 screw-driven syringe pump set to $60 \mathrm{~mL} / \mathrm{min}$.

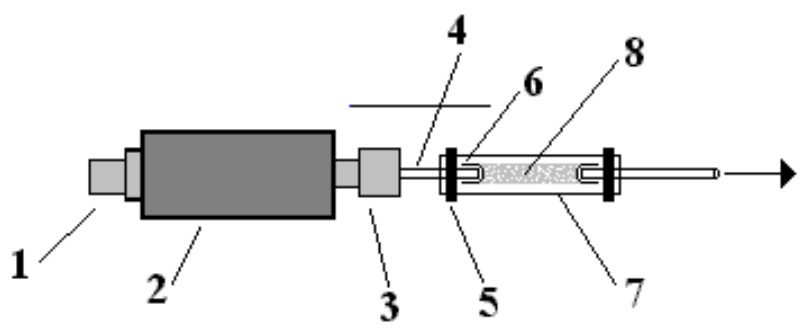

Fig. 1. Chelex $100{ }^{\circledR}$ Column Apparatus

where

1: Luer Lock, Upchurch Scientific (Oak Harbor, Washington) \#P 624

2: Plastic Union, Upchurch Scientific (Oak Harbor, Washington) \#P 623

3: Male Connector, Upchurch Scientific (Oak Harbor, Washington) \#P 345

4: 1/16" id Teflon Tubing, Upchurch Scientific (Oak Harbor, Washington) \#1523

5: Zip Tie, GB brand (Milwaukee, Wisconsin) \#45-308

6: $1 / 4$ " * 1/4" $35 \mu \mathrm{m}$ Polyester Nytex Cloth Frit

7: 1/8" id clear PVC Tubing Fisher Scientific (Pittsburgh, Pennsylvania) \#141697A

8: 200-400 mesh Chelex $100^{\circledR}$ Resin, Bio-Rad (Hercules, California) \#142-2842

Initial laboratory testing was performed in order to compare the degree of Chelex $100^{\circledR}$ resin copper retention in a fresh water $(300 \mu \mathrm{g} / \mathrm{L}$ dissolved copper, $\mathrm{pH} 6.5$ buffered with $30 \mathrm{mg} / \mathrm{L}$ calcium carbonate, $\mathrm{n}=3$ ) to a saline water (300 $\mu \mathrm{g} / \mathrm{L}$ dissolved copper, 25 parts per thousands (ppt) salinity, $\mathrm{pH}$ 8) with and without $20 \mathrm{mg} / \mathrm{L}$ organic matter in the form of Aldrich Humic Acid (Aldrich Chemical Co.). All solutions with copper and NOM were allowed to equilibrate for 24 hours before testing [21].

Preliminary laboratory tests varied copper concentration, salinity, humic acid and $\mathrm{pH}$ through adjustment by adding either $10 \mathrm{M} \mathrm{NaOH}$ or $10 \mathrm{M} \mathrm{HCl}$. One variable was modified while the others were held constant. T-tests and ANOVAs were performed to test for significant difference, and correlation coefficients were used to test for trends. 


\section{B. Chelex $100^{\circledR}$ Resin Sampling for Bioavailable Copper}

Water samples were first treated to remove particulate matter. Samples $<\mathrm{pH} 8$ were passed through $0.45 \mu \mathrm{m}$ filters; samples $\geq \mathrm{pH} 8.0$ were passed through $3.5 \mu \mathrm{m}$ glass-fiber filters because previous research demonstrated that copper sorbed to a $0.45 \mu \mathrm{m}$ filter at $\mathrm{pH}>8$ [39]. Filtered samples were passed through the Chelex $100^{\circledR}$ resin at $60 \mathrm{~mL} / \mathrm{min}$, yielding a sample detention time of approximately 0.1 seconds. The first $5 \mathrm{~mL}$ were wasted, and then the next 15 $\mathrm{mL}$ were collected for analysis. Dissolved copper retained by the Chelex $100^{\circledast}$ resin columns was operationally defined as bioavailable copper. This amount was calculated by the difference of the dissolved copper concentration before and after passing through the resin. Dissolved copper was determined by either graphite furnace atomic adsorption (Perkin-Elmer Model 5100 PC) or a Perkin-Elmer Model 703 flame atomic adsorption, in accordance to Standard Methods for the Examination of Water and Wastewater [40].

\section{Seawater, Copper and Organic Matter Solutions}

The typical salinity range for estuarine waters is $15 \mathrm{ppt}$ to 25 ppt. Four days prior to use, 50 liters of 20 ppt salinity artificial seawater (ASW) were prepared by adding $24 \mathrm{~g} / \mathrm{L}$ Instant Ocean $^{\mathrm{TM}}$ or Fathoms Crystal Sea ${ }^{\mathrm{TM}}$ to Nanopure ${ }^{\mathrm{TM}}$ water as recommended by the USEPA [41]. Salinity of $20 \mathrm{ppt}$ was confirmed by refractometer; background copper levels ranged from 1-3 $\mu \mathrm{g} / \mathrm{L}$. ASW was filtered through a 41 Whatman Filter, aerated with filtered house air, and stored in 50 -gallon carboy that was protected from light.

A dilution series of $800,400,200,100$, and $0 \mu \mathrm{g} / \mathrm{L}$ added soluble copper was prepared in ASW from Fisherbrand ${ }^{\circledR}$ copper reference solution. The added natural organic matter was Suwannee River Fulvic Acid Reference 1R101F (SRFAR), obtained from the International Humic Substances Society (Denver CO). The SRFAR is well characterized and its isolation method and chemical properties have been reported: the organic carbon content is approximately $53.3 \%$ [43]. The total organic carbon (TOC) measurement for the 12 $\mathrm{mg} / \mathrm{L}$ and $24 \mathrm{mg} / \mathrm{L}$ NOM as SRFAR were $6.0 \mathrm{mg} / \mathrm{L}$ and 12.0 $\mathrm{mg} / \mathrm{L}$ TOC, respectively, measured using a Sievers 800 TOC analyzer (Boulder, Co.). Toxicity treatments contained concentrations of 0,12 , and $24 \mathrm{mg} / \mathrm{L} \mathrm{NOM}$ in respective test chambers.

\section{Bioassay: Americamysis bahia Toxicity Test}

Larval (2 day) organisms were purchased from AquaTox Inc., Hot Springs, Arkansas, then cultured in 10 gallon tanks at salinities between 25 and 28 ppt. Mysid shrimp were acclimated to $20 \mathrm{ppt}$ ASW over a 24 hour period by addition of $20 \mathrm{ppt}$ artificial seawater (ASW) dilution water. For each toxicity replicate, $10 \pm 1$ larval shrimp were carefully pipetted to the five test solutions in quadruplicate; this method reduced impingement stress. In order to verify the health of the culture, standard 48 hour acute reference test was conducted using an EPA-certified solution of sodium dodecyl sulfate or sodium lauryl sulfate $\left(\mathrm{C}_{12} \mathrm{H}_{25} \mathrm{NaO}_{4} \mathrm{~S}\right)$. Sodium lauryl sulfate was diluted with $20 \mathrm{ppt}$ ASW at concentrations of $0,1.25,2.5,5,10,20 \mathrm{mg} / \mathrm{L}$. The $\mathrm{LC}_{50}$ was determined to be appropriate based on previous studies [42].

Artemia cysts (brine shrimp) were purchased from Argent
Chemical (Redmond, WA) and cultured in 1L conical glassware at $28^{\circ} \mathrm{C}, 24$ hour light cycle, with 2 tablespoons ASW to 1 teaspoon of cysts. The Artemia were first rinsed with deionized water then rinsed with $20 \mathrm{ppt}$ ASW. To feed the mysid shrimp, two to three drops of Artemia were added to each $500 \mathrm{ml}$ polypropylene test chamber daily.

All toxicity tests were conducted according to guidelines in USEPA Method OPPTS 850.1035 [41]. Static toxicity tests were performed in $500 \mathrm{~mL}$ polypropylene beakers with $250 \mathrm{~mL}$ of test solution, 10 mysid shrimp per replicate that were fed 100-150 Artemia once per day, and survival and immobilization as the endpoint. The light regime was 16 hours light $/ 8$ hours darkness, the $\mathrm{pH}$ ranged from 7.8 to 8.0 , with a temperature of $20^{\circ} \mathrm{C} \pm 1{ }^{\circ} \mathrm{C}$. The dissolved oxygen for all tests remained above $4.0 \mathrm{mg} / \mathrm{L}$.

\section{E. Toxicity Data and Statistical Analyses}

After tests were completed, survival data were analyzed to determine the $\mathrm{LC}_{50}$ and $\mathrm{EC}_{50}$. The number of mortalities from the acute testing was used to determine the $\mathrm{LC}_{50}$ (lethal concentration). $\mathrm{EC}_{50}$ data was measured using swimming and feeding as an activity. Methods for determination of mysid $\mathrm{EC}_{50}$ (median effective concentration) were derived by observation [44]. The $\mathrm{EC}_{50}$ was determined based on mysid immobilization. Survival and activity data were analyzed using USEPA Toxicity Data Analysis Software ${ }^{\circledR}$ (Cincinnati, $\mathrm{OH})$ to determine the $\mathrm{LC}_{50}$ and $\mathrm{EC}_{50}$. Because of observed mortality in the controls the Trimmed Spearman-Karber (TSK) method was used to calculate $\mathrm{LC}_{50}$ values and confidence limits for the toxicant exposures.

\section{RESULTS}

\section{A. Evaluation of Chelex $100^{\circledR}$ performance}

Initial laboratory testing indicated that the percent of copper bound to the resin did not differ $(p=0.31)$ between a freshwater solution ( $\mathrm{pH} 6.5$ buffered with $30 \mathrm{mg} / \mathrm{L}$ calcium carbonate) and a saline solution (25 ppt salinity at $\mathrm{pH} 8$ ). Replication by adding $20 \mathrm{mg} / \mathrm{L}$ Aldrich Humic Acid to each solution lowered the amount of copper sorbed to the resin in both cases by an equal amount $(\mathrm{p}=0.736)$ (data not shown).

Fig. 2 illustrates the effects of varying salinity, copper concentration, $\mathrm{pH}$, and humic acid on the percent Chelex $100^{\circledR}$ bound copper. In each case, one water quality parameter was varied and the others held constant. Based on Spearman correlations, there was no significant trend in percent resin bound copper with changes in total copper $\left(r_{s}=0.36, p=0.19\right)$ and changes in salinity $\left(r_{s}=-0.58, p=0.10\right)$. Increasing $\mathrm{pH}$ and organic matter as humic acid both statistically decreased percent resin bound copper, $\left(r_{s}=-0.89\right.$, $\mathrm{p}<0.01 ; \mathrm{r}_{\mathrm{s}}=-0.96, \mathrm{p}<0.01$ respectively.

\section{B. Bioassay: A. bahia Toxicity Test}

The survival of mysid shrimp during 48 hour static toxicity tests with $0,12,24 \mathrm{mg} / \mathrm{L}$ NOM combined with $0,100,200$, 400 , and $800 \mu \mathrm{g} / \mathrm{L} \mathrm{Cu}$ are shown in Fig. 3. Ninety-seven percent survival was observed in control test chambers with or without added NOM.

Complete mortality was observed at less than 48 hours for 
mysid shrimp treated with $800 \mu \mathrm{g} / \mathrm{L} \mathrm{Cu}$ and $0 \mathrm{mg} / \mathrm{L}$ NOM. A survival of greater than $60 \%$ was maintained through 48 hours for 100,200 , and $400 \mu \mathrm{g} / \mathrm{L} \mathrm{Cu}$ groups in the presence of 12 or $24 \mathrm{mg} / \mathrm{L}$ NOM. The presence of 12 or $24 \mathrm{mg} / \mathrm{L} \mathrm{NOM}$ reduced toxicity at the 100,200 , and $400 \mu / \mathrm{L} \mathrm{Cu}$ concentrations. The presence of 12 or $24 \mathrm{mg} / \mathrm{L}$ NOM did not completely protect organisms from mortality at higher concentrations however, as observed by the results at 800 $\mu \mathrm{g} / \mathrm{L} \mathrm{Cu}$. After 48 hours approximately $70 \%$ mortality was observed in mysids exposed to $800 \mu \mathrm{g} / \mathrm{L} \mathrm{Cu}$ and 12 or 24 $\mathrm{mg} / \mathrm{L}$ NOM.

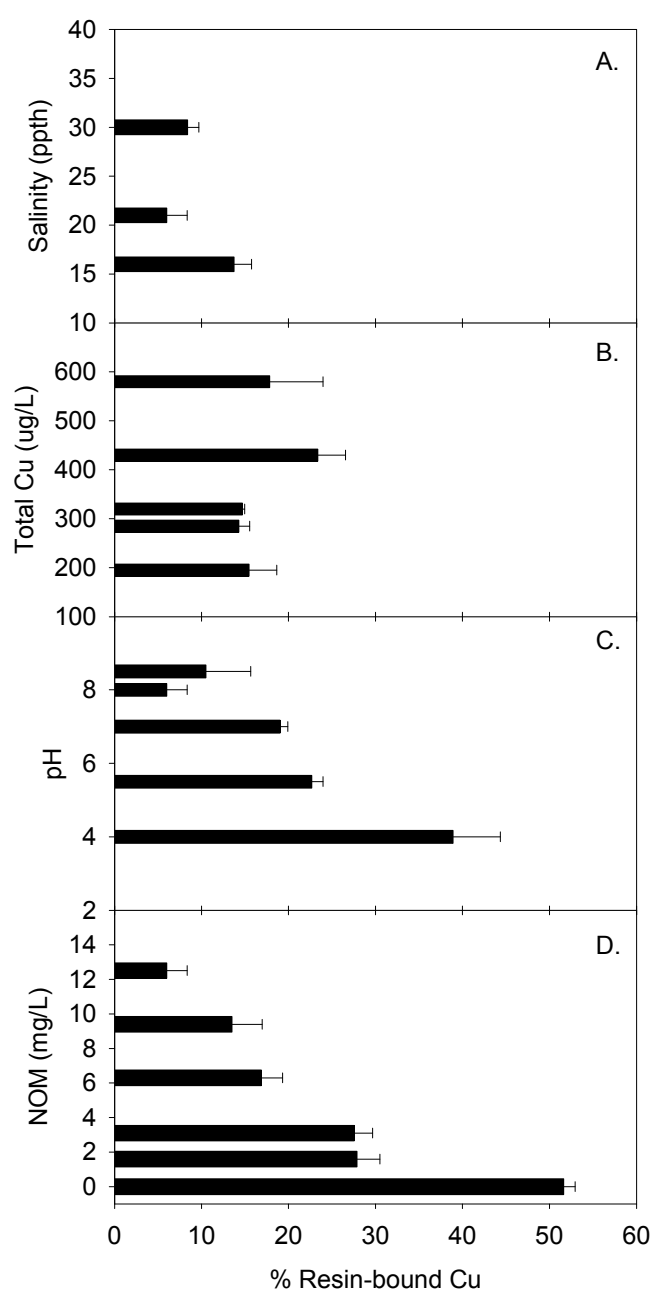

Fig. 2. Effect of water quality on Chelex $100^{\circledR}$ binding of copper; one parameter was varied while the others were held constant. Error bars represent $+/$ - standard deviation $(n=3)$.

(A) Salinity (150 $\mu \mathrm{g} / \mathrm{L} \mathrm{Cu}$ and $12.5 \mathrm{mg} / \mathrm{L}$ humic acid); (B) $\mathrm{Cu}$ Concentration ( $\mathrm{pH} 7.3,15 \mathrm{ppt}$ salinity, $12.5 \mathrm{mg} / \mathrm{L}$ humic acid); (C) pH (150 $\mu \mathrm{g} / \mathrm{L} \mathrm{Cu}, 21$ ppt salinity); (D) Humic Acid NOM, $(150 \mu \mathrm{g} / \mathrm{L} \mathrm{Cu}, 21 \mathrm{ppt}$ salinity, $\mathrm{pH} 8.1)$.

Based on the 48-hour and 96-hour toxicity tests, $\mathrm{LC}_{50}$ values of $390,200,120$, and 105 dissolved $\mu \mathrm{g} / \mathrm{L} \mathrm{Cu}$ were determined at 24, 48, 72, and 96 hours. The mysid shrimp 48-hour $\mathrm{LC}_{50}$ was determined to be $200 \mu \mathrm{g} / \mathrm{L}$ dissolved $\mathrm{Cu}$ in $0 \mathrm{mg} / \mathrm{L}$ NOM (Fig. 4), which is similar to the 48 hour $\mathrm{LC}_{50}$ of $181 \mu \mathrm{g} / \mathrm{L} \mathrm{Cu} \mathrm{LC}{ }_{50}$ for mysid shrimp reported by USEPA [45] and a 48 hour $\mathrm{LC}_{50}$ of $150 \mu \mathrm{g} / \mathrm{L}$ reported for copper chloride in 96-hour static acute toxicity tests with mysid shrimp at $25^{\circ} \mathrm{C}$ and $25 \mathrm{ppt}$ [8]. $\mathrm{EC}_{50}$ values (based on swimming and feeding) were lower than the $\mathrm{LC}_{50}$ prior to 72 hours.

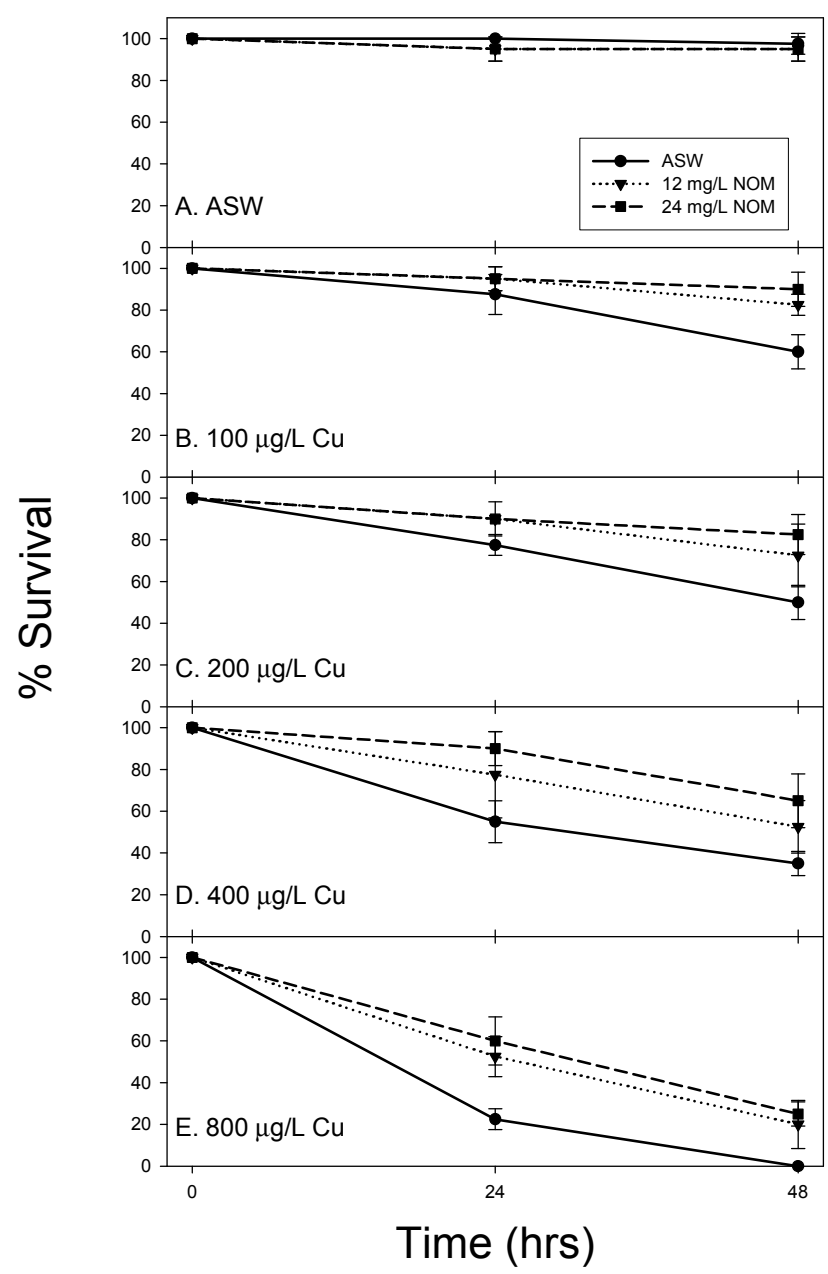

Fig. 3. Percent survivorship in 48 hour static toxicity test with $0,12,24 \mathrm{mg} / \mathrm{L}$ $\mathrm{NOM}(\mathrm{pH}$ 7.7-8.0 and $20 \mathrm{ppt})$. Error bars are $+/$ - standard deviation $(\mathrm{n}=4)$.

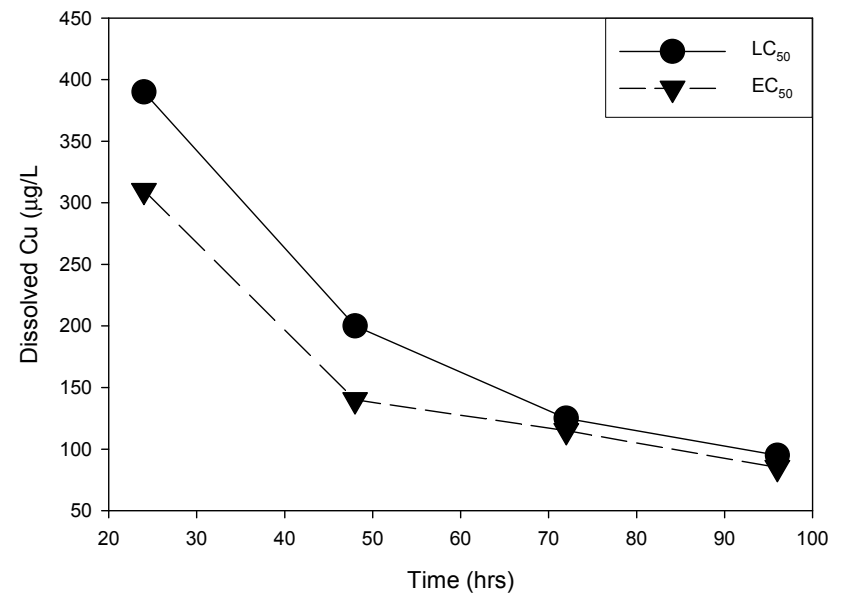

Fig. 4. A. bahia $\mathrm{LC}_{50}$ and $\mathrm{EC}_{50}$ (swimming and feeding) values for dissolved $\mathrm{Cu}$ in $0 \mathrm{mg} / \mathrm{L}$ NOM (pH 7.9, 20 ppt).

\section{A. Evaluation of Bioavailable Copper}

Fig. 5 shows the average percent resin-bound copper at 0 , $12,24 \mathrm{mg} / \mathrm{L}$ NOM and various copper concentrations. There was no statistical significant difference in \% resin-bound copper over the copper concentrations tested, although there appears to be a slight trend that percent resin-bound copper increases with an increase in total copper concentration. Fig. 
5 also displays that a larger percent of copper is resin bound in $0 \mathrm{mg} / \mathrm{L}$ NOM than by 12 and $24 \mathrm{mg} / \mathrm{L} \mathrm{NOM}$.

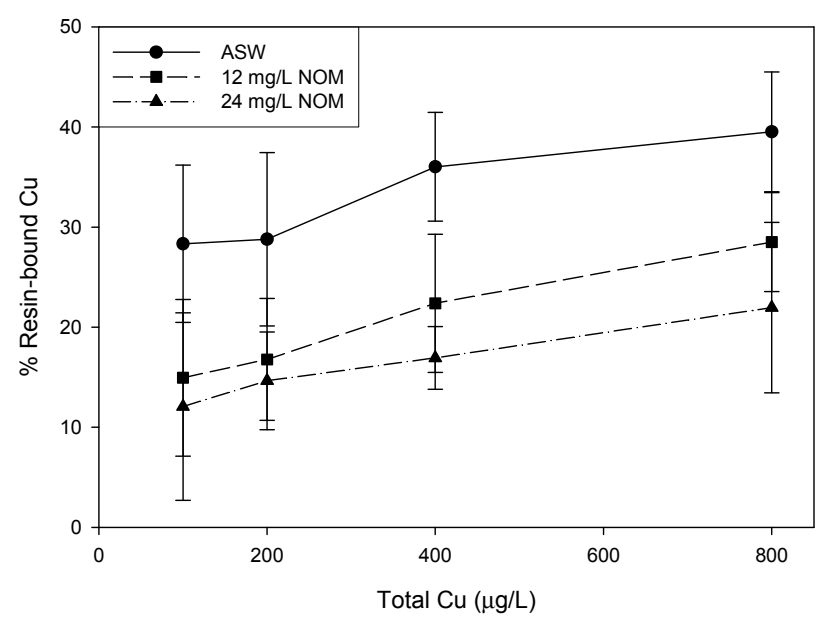

Fig. 5. Percent resin-bound copper at various NOM and copper concentrations ( $\mathrm{pH} 7.8,20 \mathrm{ppt}$ salinity, and 0, 12, $24 \mathrm{mg} / \mathrm{L} \mathrm{NOM}$ ). Error bars are $+/$ - standard deviation $(\mathrm{n}=9-11)$.

The 48-hour $\mathrm{LC}_{50}$ values for the mysid shrimp at three NOM levels are presented in Fig. 6, which illustrates the $\mathrm{LC}_{50}$ values for total, dissolved, and resin-bound copper. The 48-hour total and dissolved copper $\mathrm{LC}_{50} \mathrm{~S}$ increased with increasing concentrations of NOM. Total copper $\mathrm{LC}_{50}$ calculations were 230,400 and $540 \mu \mathrm{g} / \mathrm{L}$ total copper at 0,12 , and $12 \mathrm{mg} / \mathrm{L} \mathrm{NOM}$ respectively. Dissolved copper $\mathrm{LC}_{50}$ concentrations showed a similar trend, although the concentrations were lower. The $\mathrm{LC}_{50}$ values were 200, 340, and $495 \mu \mathrm{g} / \mathrm{L}$ dissolved copper at 0,12 , and $24 \mathrm{mg} / \mathrm{L} \mathrm{NOM}$ respectively. The $\mathrm{LC}_{50}$ values based on resin-bound copper show a very different trend however. The $\mathrm{LC}_{50}$ values were consistent across 0,12 , and $24 \mathrm{mg} / \mathrm{L}$ NOM concentrations at 94, 98, and $105 \mu \mathrm{g} / \mathrm{L}$ copper respectively. The bioassay toxicity $\mathrm{LC}_{50}$ results indicate that Chelex $100^{\circledR}$ bound copper is a more practical measure of bioavailable copper than dissolved copper in the presence of NOM.

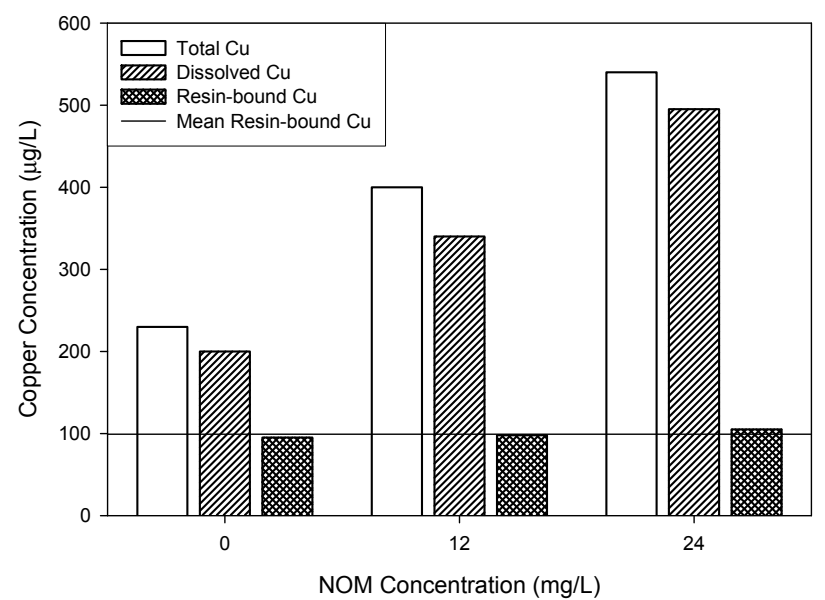

Fig. 6. Total, dissolved, and resin-bound $\mathrm{LC}_{50}$ for 0,12 , and $24 \mathrm{mg} / \mathrm{L} \mathrm{NOM}$. The black line represents the calculated mean resin-bound $\mathrm{Cu}$ concentration of $99.3 \mu \mathrm{g} / \mathrm{L}$ in the presence of 0,12 , and $24 \mathrm{mg} / \mathrm{L} \mathrm{NOM}$ (pH 7.7-8.0, $20 \mathrm{ppt}$ ).

Copper binding by NOM was also observed during the bioassay. Table I displays the initial resin-bound copper concentration, the calculated total complexed and calculated organic complexed and free estimated at 100, 200, 400, and $800 \mu \mathrm{g} / \mathrm{L} \mathrm{Cu}$ in the presence of $0,12,24 \mathrm{mg} / \mathrm{L}$ NOM. Total dissolved complexed copper estimates were determined from pre-resin analytical results. Organic complexed copper estimates were calculated by subtracting the total complexed fraction from the total complexed $0 \mathrm{mg} / \mathrm{L}$ NOM, assuming that only inorganic complexes form when no NOM was present. In addition, the calculation assumes that there was no competition between inorganic and organic binding sites. For example, the calculation of the total organic fraction at 100 $\mu \mathrm{g} / \mathrm{L} \mathrm{Cu}$ in the presence of $12 \mathrm{mg} / \mathrm{L}$ NOM was calculated by subtracting the total complexed fraction at $100 \mu \mathrm{g} / \mathrm{L} \mathrm{Cu}$ from the total complexed at $100 \mu \mathrm{g} / \mathrm{L}$ in the presence of $0 \mathrm{mg} / \mathrm{L}$ NOM. Test chambers that contained $24 \mathrm{mg} / \mathrm{L}$ NOM displayed more copper binding capacity or available sites than 0 and $12 \mathrm{mg} / \mathrm{L}$ NOM. Approximately 3 to $9 \mu \mathrm{g} / \mathrm{L}$ of $\mathrm{Cu}$ was organically complexed or bound per $1 \mathrm{mg} / \mathrm{L} \mathrm{NOM}$ during the 48 hour bioassay.

TABLE I: INITIAL RESIN-BOUND, TOTAL AND ORGANIC COMPLEXED AT 100, 200,400, AND $800 \mu \mathrm{G} / \mathrm{L}$ CU IN THE PRESENCE OF NOM.

\begin{tabular}{llrrr} 
& 200, 400, AND $800 \mu \mathrm{G} / \mathrm{L}$ CU IN THE PRESENCE OF NOM. \\
\hline Total & & \multicolumn{3}{c}{ Concentration, $\mathrm{ug} / \mathrm{L} \mathrm{Cu}$} \\
Added & \multicolumn{1}{c}{ Copper Type ${ }^{1}$} & 0 & 12 & 24 \\
Copper & Resin-bound & NOM $^{2}$ & NOM & NOM \\
\hline \multirow{3}{*}{$100 \mu \mathrm{g} / \mathrm{L}$} & Total complexed & 67 & 12 & 14 \\
& Organic complexed & 0 & 21 & 86 \\
& Resin-bound & 59 & 43 & 19 \\
\hline \multirow{3}{*}{$200 \mu \mathrm{g} / \mathrm{L}$} & Total complexed & 141 & 157 & 162 \\
& Organic complexed & 0 & 16 & 21 \\
\hline \multirow{3}{*}{$400 \mu \mathrm{g} / \mathrm{L}$} & Resin-bound & 147 & 113 & 67 \\
& Total complexed & 253 & 287 & 333 \\
& Organic complexed & 0 & 34 & 80 \\
\hline \multirow{3}{*}{$800 \mu \mathrm{g} / \mathrm{L}$} & Resin-bound & 333 & 224 & 172 \\
& Total complexed & 467 & 576 & 628 \\
& Organic complexed & 0 & 109 & 161 \\
\hline
\end{tabular}

${ }^{1}$ Total and organic complex calculated

${ }^{2} \mathrm{NOM}$ reported in $\mathrm{mg} / \mathrm{L}$

\section{DISCUSSION}

\section{A. Chelex $100^{\circledR}$ Evaluation}

Initial experiments proved that copper binding to the Chelex $100{ }^{\circledR}$ resin responded to environmental changes in a logical manner. Varying salinity from 16 to $30 \mathrm{ppt}$ did not affect percent resin bound copper. This indicated that the ions typically found in seawater did not compete with copper for ion exchange sites on the resin. Similar results were found previously for this resin in brines ranging from 35 to $250 \mathrm{~g} / \mathrm{L}$ in total dissolved salts [46].

The fraction of resin-bound copper remained constant even as the total and dissolved copper concentration increased (Fig. 2). If the system was exclusively comprised of inorganic compounds, this result is expected considering simple water chemistry theory. For example, the formation of copper carbonato complex is: $\mathrm{Cu}^{2+}{ }_{(\text {aq })}+\mathrm{CO}_{3}{ }^{2-}$ (aq) $\leftrightarrow \mathrm{CuCO}_{3}{ }^{\circ}$ (aq), yielding a stability constant of: $\mathrm{K}=$ $\left[\mathrm{CuCO}_{3}{ }^{\circ}\right] /\left[\mathrm{Cu}^{2+}\right]\left[\mathrm{CO}_{3}{ }^{2-}\right]$. Considering that $\mathrm{K}$ and $\mathrm{pH}$ are constant, if the amount of $\mathrm{Cu}^{2+}$ (aq) increases, and the concentration of $\mathrm{CO}_{3}{ }^{2-}$ (aq) is also held constant in an open system, the amount of $\mathrm{CuCO}_{3}{ }^{\circ}$ must also increase 
proportionally, thus not affecting percent bioavailability. However, this scenario is complicated in the presence of NOM. As more copper binds to NOM, the active sites may change, thus affecting $\mathrm{Cu}-\mathrm{NOM}$ complexation.

By decreasing $\mathrm{pH}$, an increase in percent resin-bound copper was observed (Fig. 2). As the $\mathrm{pH}$ of natural water is lowered, copper preferentially forms inorganic species that are potentially bioavailable. However, at $\mathrm{pH}$ below 5.5, the functional groups on the resin change, and ion exchange becomes less efficient, thus lowering the amount of resin-bound copper measured. $\mathrm{pH} \leq 4$ results in decreased resin performance compared to higher $\mathrm{pH}$ values [32], [46].

Decreasing the amount of NOM increased the percent of resin-bound copper measured (Fig. 2). As fewer binding sites were available for strong copper complexation with organic ligands, copper could be free or complexed with weaker inorganic species, thus forming potentially bioavailable species.

\section{B. Correlation of Bioavailable Copper to A. bahia Acute Toxicity}

Results of the resin-bound copper measurements and toxicity tests with the mysid shrimp indicated that NOM-bound copper reduced copper toxicity. Approximately 3 to $9 \mu \mathrm{g} / \mathrm{L}$ of $\mathrm{Cu}$ was complexed or bound per $1 \mathrm{mg} / \mathrm{L}$ NOM during the 48 hour experimental bioassay. Using the Chelex $100^{\circledR}$ resin to measure bioavailable copper, about 20 to $40 \%$ of the total copper was bioavailable in the absence of NOM, while about 10 to $20 \%$ was bioavailable when either 12 or 24 $\mathrm{mg} / \mathrm{L}$ NOM was present as Suwannee River Fulvic Acid. These results agree with many previous studies that indicate NOM mitigates copper toxicity [16], [17], [19], [41]. As copper is applied as a biocide in agriculture [5], [29], [30] and commercial aquaculture [47], [48], there is an increased need to understand its toxicity and also mitigating factors.

The toxicity tests also displayed that percent resin-bound copper were not significantly different with varying total copper concentration. These results were shown in Fig. 5. The presence of $12.5 \mathrm{mg} / \mathrm{L}$ NOM (Fig. 2) also displayed no noticeable effect of increased percent resin-bound copper concentration with increasing copper concentration. Varying initial copper concentration from 195 to $495 \mu \mathrm{g} / \mathrm{L}$ at 12.5 $\mathrm{mg} / \mathrm{L}$ NOM did not affect percent bioavailability, indicating that as the copper concentration of this water is increased over the range studied, the percentage of potentially bioavailable copper is constant, but at higher total copper concentrations a greater concentration is bioavailable and potentially toxic. The results of the NOM and saltwater experiments suggest that at different concentrations of NOM, copper may exhibit different toxicity.

\section{CONCLUSIONS}

The Chelex $100^{\circledR}$ resin was demonstrated to complex copper under conditions of varying salinity, $\mathrm{Cu}$ concentration, $\mathrm{pH}$, and NOM. Changes in salinity and total copper concentration did not affect percent resin-bound copper, whereas increases in $\mathrm{NOM}$ and $\mathrm{pH}$ decreased percent resin-bound copper. Correspondingly, acute toxicity testing with mysids indicated that NOM bound copper and thus reduced copper toxicity. Using the Chelex $100^{\circledR}$ resin method to measure bioavailable copper, about 20 to $40 \%$ of the total copper was bioavailable when no NOM was present and a dissolved copper $\mathrm{LC}_{50}$ of about $200 \mathrm{ug} / \mathrm{L}$ was observed, while about 10 to $20 \%$ was bioavailable when either 12 or 24 $\mathrm{mg} / \mathrm{L} \mathrm{NOM}$ was present and the observed $\mathrm{LC}_{50}$ was about 300-500 ug/L Cu. The Chelex $100^{\circledR}$ resin measured bioavailable copper correlated with the $\mathrm{LC}_{50}$ for mysid shrimp (A. bahia) and therefore is a useful predictor of bioavailable copper in natural estuarine and seawaters of varying water quality.

\section{ACKNOWLEDGMENT}

The authors would like to thank Jeffery Snyder, Julie Petruska and Jody Smiley for their help with analytical measurement and David Gruber and Joseph Rasnick for their assistant with the toxicity analysis.

\section{REFERENCES}

[1] R. Eisler, Copper hazards to fish, wildlife, and invertebrates: a synoptic review. Washington, D.C.: U.S. Depart. of the Interior. 1998.

[2] C. J. Keppler and A. H. Ringwood, "Effects of metal exposures on juvenile clams, Mercenaria mercenaria," Bull. Environ. Contam. Toxicol. vol. 68, pp. 43-48, 2002

[3] P. B. Merkle, D. L. Gallagher, and T. N. Solberg, "Leaching rates, metals' distribution, and chemistry of CCA treated lumber. Implications for water quality modeling," Madison, WI., Forest Products Society, pp. 69-78, 1994.

[4] N. Boulay and M. Edwards, "Copper in the urban water cycle," Crit. Rev. Environ. Sci. Technol., vol. 30, no.3, pp. 297-326, 2000.

[5] A. M. Dietrich and D. L. Gallagher, "Fate and environmental impact of pesticides in plastic mulch production runoff: field and laboratory studies," J. Agric. Food Chem., vol 50, no. 15, pp. 4409-4416, 2002.

[6] G. Lagos, Copper - environmental health criteria, World Health Organization, 1997.

[7] R. Eisler, "Electroplating wastes in marine environments: a case history at Quonset Point, Rhode Island.," In: D. J. Hoffman, B. A. Rattner, A. G. Burton, J. Cairns, G. A. J. Burton, editors. Handbook of Ecotoxicology. Boca Raton: CRC Press. pp. 44-52, 1994.

[8] [8] G. Cripe, "Comparative acute toxicities of several pesticides and metals to Mysidopsis bahia and postlarval Penaeus duorarum," Environ. Toxicol. Chem, vol. 15, no. 11, pp.1925-1930, 1994.

[9] S. N. Luoma and J. L. Carter, "Effects of trace metals on aquatic benthos, metal ecotoxicology, concepts and applications," Ecotoxicity: Concepts and Applications. Chelsea, MI: Lewis Publishers, pp. 261-300, 1991.

[10] T. M. C. LaBreche, A. M. Dietrich, D. L. Gallagher, and N. Shepherd, "Copper toxicity to larval Mercenaria mercenaria (hard clam)," Environ. Toxicol. Chem., vol. 21, no. 4, pp.760-766, 2002.

[11] R. Renner, "Water quality standards for metals toxicity," Environ. Sci. Technol., vol. 31, no. 10, pp. 466A-468A, 1997.

[12] E. Pelletier, "Chemistry of mercury, tin and lead: present status and perspectives," In: A. Tessier, D. R. Turner, editors. Metal speciation and bioavailability in aquatic systems, New York: John Wiley, pp. 103-148, 1995.

[13] R. J. Erickson, D. A. Benoit, V. R. Matterson, H. P. J. Nelson, and E. N. Leonard, "The effects of water chemistry on the toxicity of copper to fathead minnow," Environ. Toxicol. Chem., vol. 15, no. 2, pp.181-193, 1996.

[14] U.S. Environmental Protection Agency, Ambient Water Quality Criteria - Saltwater Copper Addendum. Washington, D.C.: Office of Water, 1995.

[15] H. E. Allen, D. J. Hansen, "The importance of trace metal speciation to water quality criteria," Water Environ. Res., vol. 68, no. 1, pp. 2-54, 1996.

[16] J. P. Meador, "The interaction of $\mathrm{pH}$, dissolved organic carbon, and total carbon in the determination of ionic copper and toxicity," Aquatic Toxicol., vol. 29, no. 1, pp.13-32, 1991.

[17] W. G. Sunda, A. K. Hanson, "Measurement of free cupric ion concentration in seawater by a ligand competition technique involving copper sorption onto $\mathrm{C}_{18}$ SEP-PAK cartridges," Limnology and Oceanography, vol. 32, no. 3, pp. 537-551, 1997. 
[18] H. L. Phelps, D. A. Wright, and J. A. Milhursky, "Factors affecting trace metal accumulation by estuarine oysters Crassostrea virginica," Maine Ecol vol. 22, pp. 187-197, 1993.

[19] R. W. Winner, "Bioaccumulation and toxicity of copper as affected by interactions between humic acid and water hardness," Water Research, vol. 19, pp.449-455, 1985.

[20] C. M. Davies, S. C. Apte, and A. L. Johnstone, "A bacterial bioassay for the assessment of copper bioavailability in freshwaters," Environ.Toxicol. Water Quality, vol. 13, pp. 263-271, 1998.

[21] H. Ma, S. D. Kim, D. K. Cha, and H. E. Allen, "Effect of kinetics of complexation by humic acid on toxicity of copper to Ceriodaphnia dubia," Environ. Toxicol. Chem., vol. 18, no. 5, pp. 828-837, 1999.

[22] S. Tao, T. Liang, and C. Liu, S. Xu, "Uptake of copper by neon tetras (Paracheirodon innesi) in the presence and absence of particulate and humic matter," Ecotoxicology, vol. 8, pp. 269-275, 1999.

[23] J. M. Besser, W. G. Brumbaugh, T. W. May, C. G. Ingersoll, "Effects of organic amendments on the toxicity and bioavailability of cadmium and copper in spiked formulated sediments," Environ.Toxicol. Chem, vol. 21 , no. 3, pp. 805-815, 2003.

[24] D. B. Buchwalter, G. Linder, and L. R. Curtis, "Modulation of cupric ion activity in $\mathrm{pH}$ and fulvic acid as determinants of toxicity in Xenopus laevis embryos and larvae," Environ. Toxicol. Chem., vol. 15, no. 4, pp. $568-57,1996$.

[25] A. M. Mota and M. M. Correida dos Santos, "Trace metal speciation of labile chemical species in natural waters: electrochemical methods," in: A. Tessier, D. R. Turner, editors. Metal speciation and bioavailability in aquatic systems. New York: John Wiley. p 205-258, 1995.

[26] M. B. Kogut and B. M. Voekler, "Strong copper-binding behavior in terrestrial humic substances in seawater," Environ. Sci. Technol., vol. 35, no. 6, pp. 1149-1156, 2001.

[27] K. W. Bruland, E. L. Rue, J. R. Donat, S. A. Skrabal, and J. W. Moffett, "Intercomparison of voltammetric techniques to determine the chemical speciation of dissolved copper in a coastal seawater sample," Anal. Chim. Acta, vol. 405, pp. 99-113, 2000.

[28] Y. Lu and H. E. Allen, "Characterization of copper complexation with natural dissolved organic matter (DOM) - link to acidic moieties of DOM and competition by Ca and Mg," Water Research, vol. 36, pp.5083-5101, 2002.

[29] A. M. Dietrich, D. L. Gallagher, and K. Klawiter, "Inputs of copper-based crop protectants to coastal creeks from plasticulture runoff," J. American Water Res. Assoc., vol. 37, no. 2, pp. 281-294, 2001.

[30] D. L. Gallagher, K. M. Johnston, and A. M. Dietrich, "Fate and transport of copper-based crop protectants in plasticulture runoff and the impact of sedimentation as a best management practice," Water Research, vol. 35, no. 12, pp. 2984-2994, 2001.

[31] E. Deaver and J. H. Rodgers, Jr.," "Measuring bioavailable copper using anodic stripping voltammetry," Environ. Toxicol. Chem., vol. 15, no. 11, pp. 1925-1930, 1996.

[32] C. N. Mazidji, B. Koopman, G. Bitton, "Chelating resin versus ion exchange resin for heavy metal removal in toxicity fractionation," Water Sci. Technol., vol. 26, no. 1-2, pp. 189-196, 1992.

[33] C. L. Chakrabarti, Y. Lu, D. C. Gregoire, M. H. Back, and W. H. Schroeder, "Kinetic studies of metal speciation using Chelex cation exchange resin: application to cadmium, copper, and lead speciation in river water and snow,” Environ. Sci. Technol., vol. 28, pp. 1957-1967, 1994.

[34] M. Pesaventa, G. Alberti, and A. Profumo, "Determination of the metal complexing capacity of aqueous solutions containing ligands by titration in the presence of complexing resins," Anal. Chim. Acta 405:309-319, 2000.

[35] M. Pesaventa and R. Biesuz, "Sorption of divalent metal ions on a iminodiacetic resin from artificial seawater." Anal. Chim. Acta, vol. 346, pp. 381-39, 1997.

[36] M. Pesaventa, R. Biesuz, "Simultaneous determination of total and free metal ion concentration in solution by sorption on imonodiacetate resin," Analyt. Chem., vol. 67, pp. 3558-3563, 1995.

[37] M. Pesaventa, R. Biesuz, M. Gallorina, and A. Profumo, "Sorption mechanism of trace amounts of divalent metal ions on a chelating resin containing iminodiacetate groups," Analyt. Chem., vol. 65, pp. 2522-2527, 1993.

[38] T. Miwa, M. Murakami, and A. Mizuike, "Speciation of copper in fresh water," Anal. Chim. Acta, vol. 219, no. 1, pp. 1-8, 1989.

[39] L. Hidmi and M. Edwards, "Role of temperature and $\mathrm{pH}$ in $\mathrm{Cu}(\mathrm{OH})_{2}$ solubility," Environ. Sci. Technol., vol. 33, pp. 2607-2610, 1999.

[40] American Public Health Association AWWA, Water Pollution Control Federation, Standard Methods for the Examination of Water and Wastewater, Washington, D.C.: American Public Health Association, 1998.

[41] U.S. Environmental Protection Agency, Methods for measuring the acute toxicity of effluents and receiving waters to freshwater and marine organisms, Cincinnati, $\mathrm{OH}$ : Office of Research and Development, U.S. Environmental Protection Agency. Report nr EPA 600/4-90/027, 1991.

[42] D. T. Burton and D. J. Fisher, "Acute toxicity of cadmium, copper, zinc, ammonia, 3,3'-dichlorobenzidine, 2, 6-dichloro-4-nitroaniline, methyle chloride, and 2,4,6-trichlorophenol to juvenile grass shrimp and killifish," Bull. Environ. Contam. Toxicol., vol. 44, no. 5, pp. 776-783, 1990.

[43] C. F. Lin, D-Y. Lee, W-T. Chen, and K. S. Lo, "Fractionation of fulvic acids: characteristics and complexation with copper," Environ. Pollut,. vol. 87 , no. 2, pp. 181-187, 1995 .

[44] G. M. Rand and S. R. Petrocelli, Fundamentals of aquatic toxicology methods and applications. New York: Hemisphere Publishing, 1984.

[45] U.S. Environmental Protection Agency, Ambient Water Quality Criteria for Copper, Washington D.C.: Office of Water, 1985.

[46] M. Kuhn, C. Niewohner, M. Isenbeck-Schroter, and H. D. Schulz, "Determination of major and minor constituents in anoxic thermal brines of deep sandstone aquifers in northern Germany," Water Research, vol. 32, no. 2, pp. 265-274, 1998.

[47] D. J. Mayor, M. Solan, I. Martinez, L. Murray, H. McMillan, G.I. Paton, and K. Killham, "Acute toxicity of some treatments commonly used by the salmonid aquaculture industry to Corophium volutator and Hediste diversicolor: Whole sediment bioassay tests," Aquaculture, vol. 285 , no. 1-4, pp. 102-108, 2008.

[48] A. Tom-Petersen, K. K. Brandt, O. N. Niels, and O.G. Jørgensen, "Copper bioavailability and impact on bacterial growth in flow-through rainbow trout aquaculture systems." Aquaculture, vol. 322-323, no. 21 pp. 259-262, 2011. 